\title{
Gambaran Kadar Glukosa Urin pada Primigravida dengan Orang Tua Penyandang Diabetes Melitus di Kota Manado
}

\author{
${ }^{1}$ Monica Welliangan \\ ${ }^{2}$ Mayer F. Wowor \\ ${ }^{2}$ Arthur E. Mongan
}

\author{
${ }^{1}$ Program Studi Pendidikan Dokter Fakultas Kedokteran Universitas Sam Ratulangi Manado \\ ${ }^{2}$ Bagian Ilmu Patologi Klinik Fakultas Kedokteran Universitas Sam Ratulangi Manado \\ Email: mwelliangan@gmail.com
}

\begin{abstract}
Glycosuria is a condition characterized by an excess of sugar in the urine. Diabetes mellitus (DM) is one of the causes of glycosuria. Mortality risks of pregnant women and their babies increase in diabetes during pregnancy. Gestational diabetes mellitus (GDM) is DM diagnosed in 2nd and 3rd trimesters of pregmancy in women without DM before pregnancy. The probability of GDM among women with family history of DM is 3.46 times higher than those without family history. This study was aimed to evaluate the urine glucose level among primigravids who had diabetic parents in Manado. This was a descriptive observational study with a cross sectional design. Urine samples were obtained by using non-probability sampling with consecutive sampling adjusted to the criteria and time. The results showed that glycosuria (urin sugar level $\geq 50 \mathrm{mg} / \mathrm{dL}$ ) was found in three subjects (10\%), most in age group of 20-35 years old and in 1st trimester. Conclusion: Some of the primigravids in this study had glycosuria.
\end{abstract}

Keywords: DM, glycosuria, DM family history

\begin{abstract}
Abstrak: Glukosuria adalah kondisi dimana glukosa ditemukan dalam urin. Salah satu penyebab glukosuria ialah diabetes melitus (DM). Risiko kematian ibu dan bayi meningkat pada DM dalam kehamilan. Diabetes melitus gestasional (DMG) adalah DM yang terdiagnosis pada trimester dua atau tiga kehamilan yang bukan DM sebelum kehamilan. Peluang DMG pada wanita dengan riwayat DM dalam keluarga sebesar 3,46 lebih besar daripada wanita tanpa riwayat keluaarga. Penelitian ini bertujuan untuk mengetahui kadar glukosa urin pada primigravida dengan orang tua penyandang DM di Kota Manado. Jenis penelitian ialah deskriptif observasional dengan desain potong lintang. Penelitian ini menggunakan nonprobability sampling jenis consecutive sampling untuk mendapatkan urin dari semua subyek penelitian sesuai dengan kriteria dan waktu yang ditentukan. Hasil penelitian mendapatkan glukosuria (kadar glukosa urin $\geq 50 \mathrm{mg} / \mathrm{dL}$ ) pada 3 subyek (10\%) dengan karakteristik cenderung pada kelompok usia 20-35 tahun dan pada trimester satu. Simpulan: Sebagian primigravida dengan orang tua penyandang DM memiliki glukosuria.
\end{abstract}

Kata kunci: DM, glukosuria, riwayat DM pada orang tua

Kematian bayi adalah kematian yang terjadi antara setelah bayi lahir sampai berusia satu tahun. ${ }^{1}$ Tujuan Millenium Development Goals (MDGs) dalam menurunkan kematian bayi dari 68 kematian per 1.000 kelahiran tahun 1991 menjadi 23 kematian per 1.000 kelahiran di tahun 2015 belum terlaksana, dilihat dari kematian bayi menurut Survei Demografi dan Kesehatan Indonesia (SDKI) 2012 sebanyak 32 bayi per 1.000 kelahiran. ${ }^{2}$ Data rekapitulasi dari program kesehatan anak, didapatkan bahwa 
sepanjang tahun 2016 terdapat 250 kasus kematian bayi di Sulawesi Utara. ${ }^{1}$ Risiko kematian ibu dan bayi meningkat pada diabetes melitus (DM) dalam kehamilan. ${ }^{3}$

Kejadian DM dalam kehamilan dipengaruhi oleh keadaan wanita hamil yang memiliki genetik atau riwayat DM dalam keluarga, obesitas/overweight, glukosuria, dan riwayat pre-eklamsia. Penelitian di Jember menunjukkan wanita hamil dengan DM dan glukosuria memiliki hubungan yang kuat yaitu 17 pasien $(89,5 \%)$ dari total 19 pasien. $^{4}$

Komplikasi DM pada kehamilan memengaruhi ibu dan bayi. Malformasi kongenital ialah komplikasi yang paling sering terjadi pada bayi saat awal kehamilan. ${ }^{3}$ Risiko pre-eklampsia, operasi sesar (yang direncanakan atau darurat) dan distosia bahu bayi meningkat pada wanita hamil dengan DM. ${ }^{5}$

Diabetes melitus gestasional (DMG) adalah DM yang terdiagnosis pada trimester dua atau tiga kehamilan pada wanita yang bukan DM sebelum kehamilan. ${ }^{6}$ Hasil temuan dari penelitian yang dilakukan di Iran menunjukkan DMG berhubungan dengan riwayat DM dalam keluarga. Peluang DMG pada wanita dengan riwayat DM dalam keluarga sebesar 3,46 lebih besar dari pada wanita tanpa riwayat keluarga. Data ini menunjukkan pemeriksaan wanita hamil dengan riwayat DM dalam keluarga dapat mengarahkan pada pemeriksaan awal DMG dan dapat meningkatkan ukuran pelayanan kesehatan primer. $^{7}$

Diagnosis DM yang paling dasar yaitu dengan ditemukannya hiperglikemia. Konfirmasi gejala hiperglikemia terjadi dengan ditemukannya glukosuria dan kadar gula darah puasa (GDP) di atas $200 \mathrm{mg} / \mathrm{dL}$. Pemeriksaan pada pasien tanpa gejala dapat dilakukan dengan bantuan pemeriksaan urin, tes gula darah sewaktu (GDS), tes GDP, tes toleransi glukosa oral, dan lainnya. ${ }^{8}$

Asal pemeriksaan urin secara visual dimulai pada masa Mesir kuno. Hippocrates (sekitar 400 SM) menemukan karakteristik urin (bau/warna) berbeda pada setiap penyakit. ${ }^{9}$ Urinalisis merupakan tes diagnostik urin paling sederhana. Indikasi pemeriksaan urinalisis yaitu curiga adanya gangguan ginjal seperti gagal ginjal, pielonefritis, sindrom glomerulonefritis dan sindrom nefrotik, mendeteksi infeksi saluran kemih, mendeteksi gangguan metabolik seperti DM, mencari diagnosis banding jaundice, mendeteksi plasma sel diskrasia, dan diagnosis kehamilan. ${ }^{10}$ Glukosuria adalah kondisi dimana glukosa ditemukan dalam urin (biasanya saat glukosa serum $>180 \mathrm{mg} / \mathrm{dL}) .{ }^{11} \quad$ Ekskresi glukosa dalam urin terjadi bila kadar glukosa dalam darah meningkat dan tidak dapat direabsorpsi. ${ }^{12}$

Penelitian ini bertujuan untuk mengetahui gambaran kadar glukosa urin pada primigravida dengan orang tua penyandang DM di Kota Manado.

\section{METODE PENELITIAN}

Penelitian ini merupakan studi deskriptif observasional dengan desain potong lintang yang dilaksanakan di 4 puskesmas di Kota Manado, yaitu Puskesmas Ranomut, Puskesmas Ranotana Weru, Puskesmas Tikala Baru, dan Puskesmas Tuminting. Pemeriksaan sampel urin dilaksanakan di Laboratorium Pro-Kita Manado. Populasi penelitian ialah wanita primigravida dengan orang tua penyandang DM. Populasi terjangkau adalah wanita hamil primigravida dengan orang tua penyandang diabetes melitus di Kota Manado. Sampel penelitian adalah sampel urin sewaktu dari semua wanita hamil yang memenuhi kriteria inklusi dan eksklusi. Sampel diambil dengan cara nonprobability sampling jenis consecutive sampling untuk mendapatkan urin dari semua wanita hamil dalam kurun waktu dan kriteria yang telah ditentukan.

Data yang diperoleh diolah dalam bentuk tabel, dan selanjutnya disusun secara komputerisasi menggunakan program Microsoft Excel.

\section{HASIL PENELITIAN}

Penelitian yang dilakukan di empat puskesmas di Kota Manado, yaitu 
Puskesmas Ranomut, Puskesmas Ranotana Weru, Puskesmas Tikala Baru, dan Puskesmas Tuminting selama bulan Oktober - Desember 2018 mendapatkan 30 sampel urin primigravida dengan orang tua penyandang DM. Sampel penelitian tersebut didapatkan dari 6 orang $(20 \%)$ berusia $\leq 19$ tahun, 24 orang $(80 \%)$ berusia $20-35$ tahun, dan 0 orang $(0 \%)$ berusia $\geq 36$ tahun.

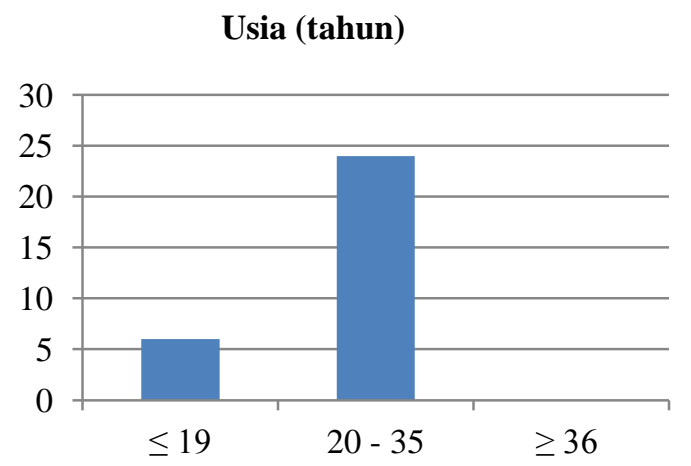

Gambar 1. Distribusi sampel berdasarkan usia

Sampel yang diambil terbagi dalam beberapa trimester (Gambar 2). Trimester 1 adalah wanita hamil pada minggu 0-12 kehamilan; trimester 2 pada minggu 13-27 kehamilan; dan trimester 3 pada minggu 28-40 kehamilan. Pembagian ini memperlihatkan 7 orang $(23,3 \%)$ pada trimester I, 10 orang $(33,3 \%)$ pada trimester II, dan 13 orang $(43,3 \%)$ pada trimester III.

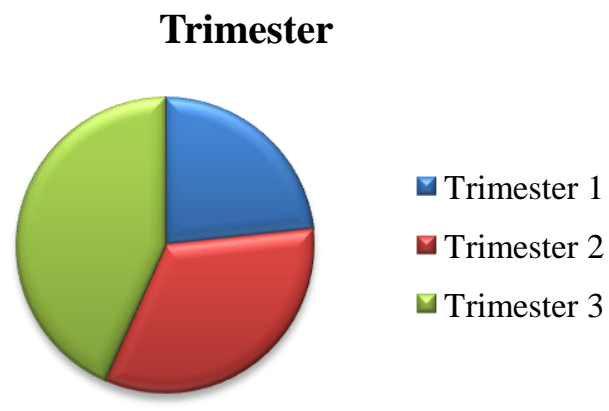

Gambar 2. Distribusi sampel berdasarkan trimester

Tabel 1 memperlihatkan gambaran distribusi sampel berdasarkan kadar glukosa urin dengan hasil 27 orang $(90 \%)$ memilki kadar normal/negatif, 3 orang (10\%) dengan hasil positif $(+), 0$ orang $(0 \%)$ dengan hasil positif $(++), 0$ orang $(0 \%)$ dengan hasil positif $(+++)$, dan 0 orang $(0 \%)$ dengan hasil positif $(++++)$.

Tabel 1. Distribusi berdasarkan kadar glukosuria

\begin{tabular}{ccc}
\hline Kadar & Frekuensi & $\begin{array}{c}\text { Persentase } \\
(\boldsymbol{\%})\end{array}$ \\
\hline Normal/Negatif & 27 & 90 \\
$+(\geq 50 \mathrm{mg} / \mathrm{dL})$ & 3 & 10 \\
$++(\geq 100 \mathrm{mg} / \mathrm{dL})$ & 0 & 0 \\
$+++(\geq 300 \mathrm{mg} / \mathrm{dL})$ & 0 & 0 \\
$++++(\geq 1000 \mathrm{mg} / \mathrm{dL})$ & 0 & 0 \\
Total & 3 & 100 \\
\hline
\end{tabular}

Gambar 3 memperlihatkan gambaran distribusi glukosuria berdasarkan usia sesuai dengan pembagian usia yang terlihat pada Gambar 1. Sampel dengan glukosuria didapatkan 1 orang $(33,3 \%)$ pada usia $\leq 19$ tahun, 2 orang $(66,6 \%)$ pada usia $20-35$ tahun, dan 0 orang $(0 \%)$ pada usia $\geq 36$ tahun.

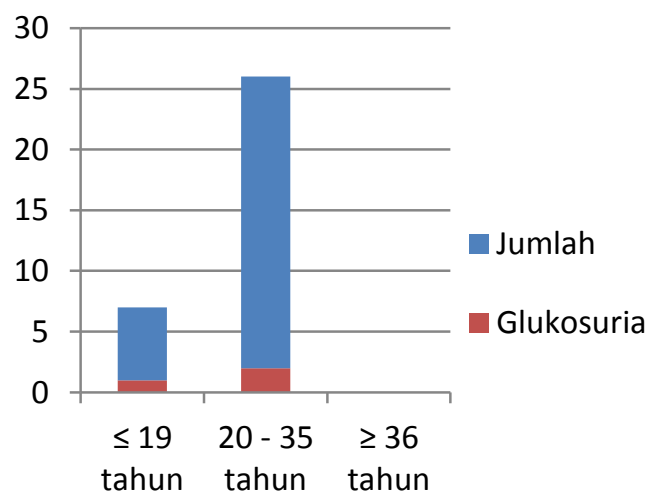

Gambar 3. Distribusi glukosuria berdasarkan usia

Tabel 2 memperlihatkan gambaran distribusi glukosuria berdasarkan trimester sesuai dengan pembagian trimester pada Gambar 2. Sampel dengan glukosuria didapatkan 2 orang $(66,6 \%)$ pada trimester I, 0 orang $(0 \%)$ pada trimester II, dan 1 orang $(33,3 \%)$ pada trimester III. 
Tabel 2. Distribusi trimester berdasarkan trimester

\begin{tabular}{ccc}
\hline Trimester & Frekuensi & $\begin{array}{c}\text { Persentase } \\
(\%)\end{array}$ \\
\hline Trimester I & 2 & $66,6 \%$ \\
$(0-12$ minggu $)$ & & $0 \%$ \\
Trimester II & 0 & $33,3 \%$ \\
$(13-27$ minggu $)$ & & $100 \%$ \\
Trimester III & 1 & \\
$(28-40$ minggu $)$ & 3 & \\
Total & & \\
\hline
\end{tabular}

\section{BAHASAN}

Pada penelitian ini, kelompok usia primigravida yang paling banyak pada kelompok usia 20-35 tahun (Gambar 1). Hasil penelitian ini sesuai dengan penelitian oleh Said $^{13}$ yang mendapatkan usia primigravida terbanyak pada rentang usia 20-35 tahun (60\%). Data SDKI 2017 menunjukkan angka kematian perinatal lebih besar pada ibu yang melahirkan di usia muda dan usia tua dibandingkan pada ibu usia 20 - 39 tahun. $^{14}$

Sampel urin penelitian ini diambil pada beberapa trimester (Gambar 2). Jumlah sampel dalam pembagian trimester tidak sama, dengan trimester III terbanyak diikuti trimester II dan I. Hasil penelitian ini sesuai dengan penelitian oleh Mahmuda ${ }^{15}$ yang menunjukkan ibu hamil paling banyak memeriksakan kehamilan pada trimester III $(57 \%)$ diikuti trimester II $(32 \%)$ dan tirmester I (11\%). Perbedaan jumlah ibu hamil pada setiap trimester berhubungan dengan pengetahuan ibu hamil terhadap pemeriksaan kehamilan, biaya pemeriksaan dan kepatuhan terhadap jadwal pemeriksaan.

Primigravida dengan glukosa urin normal lebih banyak dibandingkan dengan yang memiliki glukosa urin positif (+) yaitu 3 sampel (10\%) (Tabel 1). Kadar glukosa urin berhubungan erat dengan kadar glukosa darah. Peningkatan gluksoa darah, terutama pada GDM dipengaruhi oleh beberapa faktor. Faktor yang paling mungkin pada penelitian ini adalah primigravida dan riwayat keluarga diabetes melitus.
Hasil penelitian ini memperlihatkan bahwa pada kelompok usia 20-35 tahun lebih banyak ditemukan glukosuria dibandingkan pada kelompok usia $\leq 19$ tahun (Gambar 3). Hal ini sesuai dengan penelitian oleh Klein ${ }^{16}$ yang menunjukkan rerata usia ditemukannya glukosuria pada ibu hamil ialah usia 30 tahun. Glukosuria adalah kondisi dimana glukosa ditemukan dalam urin (biasanya saat glukosa serum $>180 \mathrm{mg} / \mathrm{dL}) .{ }^{11}$ Ekskresi glukosa dalam urin dapat terjadi bila kadar glukosa dalam darah meningkat dan tidak dapat direabsorpsi. ${ }^{12}$ Wanita usia lanjut di atas 35 tahun berhubungan dengan prognosis buruk pada kehamilan. Alasan kejadian ini terjadi karena insidensi kondisi medik kronik lebih tinggi pada wanita yang lebih tua. ${ }^{17}$

Pada penelitian ini, sampel dengan glukosuria didapatkan 2 orang $(66,6 \%)$ pada trimester I dan 1 orang $(33,3 \%)$ pada trimester III (Tabel 2). Kejadian glukosuria lebih bannyak terjadi pada kelompok trimester I dibandingkan pada kelompok trimester II atau III. Glukosa urin dapat menjadi salah satu penanda terjadinya DMG. Wanita yang terdiagnosis sebagai diabetes pada trimester I diklasifikasikan sebagai pre-gestasional diabetes. DMG adalah diabetes yang pertama kali terdiagnosis pada trimester ke-II atau ke-III kehamilan yang bukan pre-gestasional diabetes tipe 1 atau tipe $2 .^{6}$ Gejala DMG berhubungan dengan resistensi insulin fisiologis yang berkembang saat kehamilan. Kebutuhan insulin tidak berubah hingga minggu ke-18 kehamilan, sedangkan peningkatan terjadi pada minggu ke-28 kehamilan. Besarnya perubahan berbeda untuk setiap orang, yang diasumsikan karena perbedaan fungsi plasenta. ${ }^{18}$

Riwayat keluarga ialah faktor risiko yang kuat untuk DM, tetapi faktor yang menyebabkan risiko ini masih kurang dipahami. Indeks massa tubuh, lingkar pinggang, dan skor genetik memiliki hubungan yang kecil dengan riwayat keluarga DM. Risiko terbesar terlihat pada riwayat DM kedua orang tua dan riwayat orang tua yang didiagnosis dengan DM 
pada usia lebih muda ( $<50$ tahun) terutama pada riwayat keluarga maternal. ${ }^{19}$

Limitasi penelitian ini ialah sebaran pengambilan sampel tidak merata di seluruh Kota Manado karena keterbatasan sumber daya dan distribusi penduduk, jumlah sampel yang digunakan dalam penelitian masih kurang, serta anamnesis dan kuesioner yang digunakan dalam penelitian belum mewakili semua faktor yang menyebabkan terjadinya glukosuria

\section{SIMPULAN}

Berdasarkan hasil penelitian ini dapat disimpulkan bahwa sebagian primigravida dengan orang tua penyandang diabetes $(10 \%)$ memiliki kadar glukosa urin + $(\geq 50 \mathrm{mg} / \mathrm{dL})$.

\section{SARAN}

Disarankan pada penelitian lanjut agar meningkatkan jumlah sampel dan waktu penelitian untuk menghindari terjadinya bias dalam penelitian. Juga diperlukan pemeriksaan indeks massa tubuh dan anamnesis lebih lanjut untuk melengkapi semua faktor-faktor penyebab glukosuria.

Wanita hamil dengan glukosuria dianjurkan untuk pemeriksaan gula darah puasa (GDP) dan tes toleransi glukosa oral (OGTT) untuk mendapatkan diagnosis DMG sehingga dapat mecegah komplikasi lanjut.

\section{DAFTAR PUSTAKA}

1. Dinas Provinsi Sulawesi Utara. Profil Kesehatan Provinsi Sulawesi Utara 2016. Manado, 2017; p. 17-18.

2. Direktorat Statistik Kependudukan dan Ketenagakerjaan BPS. Kajian indikator lintas sektor: potret awal tujuan pembangunan berkelanjutan (sustainable development goals) di Indonesia. Jakarta: 2017; p. 48.

3. Bhowmlk B. First trimester complications in pregnancy with diabetes. Journal of Pakistan Medical Association. 2016; 66:78.

4. Meggeria P, Pudjo W, Prasetyowati I. Gambaran kondisi ibu hamil dengan diabetes melitus di RSD dr. Soebandi Jember tahun 2013-2017. E-jurnal
Pustaka Kesehatan. 2018;6:48.

5. Ovesen PG, Jensen DM, Damm P, Rasmussen S, Kesmodel US. Maternal and neonatal outcames in pregnancies complicated by gestasional diabetes. J Matern.-Fetal Neonatal Med. 2015;28:1720-1724.

6. American Diabetes Association. Standards of Medical Care in Diabetes-2018. Diabetes Care. 2018;41(Supl 1):S55S64.

7. Moosazadeh M, Asemi Z, Lankarani KB, Tabrizi R, Maharlouei N, NaghibzadehTahami A, et.al. Family history of diabetes and the risk of gestasional diabetes melitus in Iran: A systematic review and meta-analysis. Diabetes \& Metabolic Syndrome: Clinical Research \& Reviews. 2016 (article in press).

8. Harsh M. Textbook of Pathology (6th ed). India: Jaypee Brothers Medical Publishers, 2010; p. 652, 826-28.

9. Roche. Compendium of urinalysis urine test strips and microscopy. p.18-9.

10. Kawthalkar S. Essentials of Clinical Pathology. India: Jaypee Brothers Medical Publishers, 2010; p. 3-16.

11. Wilson D. McGraw-Hill's Manual of Laboratory Diagnostic Tests. Illionis: McGraw-Hill Education, 2008; p. 5889.

12. Sherwood L. Human Physiology from Cells to Systems (9th ed). Canada: Cengange Learning, 2014; p. 496-512.

13. Said N, Kanine E, Bidjuni H. Hubungan faktor sosial ekonomi dengan kecemasan ibu primigravida di Puskesmas Tuminting. Ejournal Keperawatan. 2015;3:4.

14. Badan Kependudukan dan Keluarga Berencana Nasional, Badan Pusat Statistik, Kementerian Kesehatan, USAID. Survei Demografi dan Kesehatan Indonesia 2017. Jakarta: 2018; p.144.

15. Mahmuda S, Akhter N, Pervin F, Asafudullah S, Habib M. Glycemic status during different trimester of pregnancy. KYAMC Journal. 2017; 7:792.

16. Klein P, Polidori D, Twito O, Jaffer A. Impaired decline in renal threshold for glucose during pregnancy-a possible novel mechanism for 
gestasional diabetes melitus. Diabetes Metab Res Rev. 2014;30(2):140-5.

17. Lamminpaa R. Advanced maternal age, pregnancy and birth [Disertasi]. Finland: University of Eastern Finland; 2015.

18. Holt R, Cockram C, Flyvbjerg A, Goldstein B, editors. Textbook of Diabetes (4th ed). Singapore:
Blackwell Publishing, 2010; p. 889.

19. Scott RA, Langenberg C, Sharp SJ, Franks PW, Rolandsson O, Drogan D, et.al. The link between family history and risk of type 2 diabetes is not explained by anthropometric, lifestyle, of genetic risk factors: the EPIC-Iner Act Study. Diabetologia. 2013;56:60-9. 